\title{
Downstream Changes on a Tropical Fish Community Structure by Effluent from Wood Processing Factory
}

\author{
Benedict Obeten Offem*, Irom Bassey, Gabriel Ujong Ikpi \\ Department of Fisheries and Aquatic Sciences, Cross River University of Technology, Cross River State, Nigeria. \\ Email: *benbeff06@yahoo.com
}

Received June $1^{\text {st }}, 2011$; revised July $6^{\text {th }}, 2011$; accepted August $5^{\text {th }}, 2011$.

\begin{abstract}
In order to plan a management programme for ensuring maximum production of fish in Cross River, impacted downstream changes in the fish community structure by effluents from wood processing industry, six years after establishment, was examined. Monthly samples were collected between January and December each year from 2000 to 2006 in three reaches (Upriver: I, Mid-river: II and Downriver: III) along the length of Cross River. Representatives of the fish families Osteoglossidae (i.e. Heterotis niloticus), Cichlidae (Tilapia melonopleura) and Characidae (Bryocinus nurse), Clupeidae (Cynothrissa sp), Mormyridae (Mormyrus deliciosus), Clariidae (Clarias gariepinus), Bagridae (Bagrus bayad) and Cyprinidae (Barbus occidentalis) were found to have declined in their importance compared to pre-industry period. On the other hand, Bagridae (Chrysichthys nigrodigitatus), Cichlidaae (Orechromis niloticus), Claridae (Clarias anguillaris) and Mochokidae (Synodontis clarias) have currently emerged as most important. Estimated value of growth coefficient $(b)$ of the length-weight relationship changed from isometry $(b$ approx. $=3$ ) to negative allometry $(b \leq 3)$, condition factor values decreased from range between 0.53 and 1.30 to range between 0.22 and 0.62 . Main feeding groups of fish; planktivores, carnivores and insectivores declined in numbers while omnivores and detritivores increased, resulting in dominance of benthic and semi-pelagic omnivores. Values of fecundity distribution varied from $56,012 \pm 5234$ eggs, mode 12,500 and median 58,345 to mean value 23,122 \pm 232 eggs, mode 2500 and median 20,349, egg size from mean value; $1.82 \pm 0.07 \mathrm{~mm}$, mode 2.2 , and median; 1.8 to values of $0.8 \pm 0.04 \mathrm{~mm}$, mode; 1.3 and median 1.1 and Gonadosomatic index from $20.5 \pm 3.2$, mode $19.1 \pm 2.2$ and median 21.4 to values of $12.4 \pm 2.3$, mode 4.5 and median 9.5 respectively. Three species found to have appeared in the river were Tilapia monody, Chrysichthys maurus and Synodontis violaceus. The appearance of these species and disappearance of 36 others indicates the restructuring of the fish community of the Cross River by effluents from the wood processing industry.
\end{abstract}

Keywords: Fish Community, Fish Composition and Abundance, Diet Changes, Length-Weight Relationship, Reproductive Biology

\section{Introduction}

In Africa, a large proportion of both rural and urban populations live in vicinity of inland or coastal waters. Examples are Cairo on River Nile, Khartoun at Confluence of blue and white nile, Kampala (Lake Victoria), Kinshasa and Brazaville (River Zarie/Congo), Banjul (River Gambia), Niamey and Bamako (River Niger) and some national capitals located along the coast e.g Abidjan, Dakar, Rabat, Da Es Salam and Luanda [1]. Settlements close to natural waters offer man's greatest hopes for livelihood and material supplies. Egypt's Delta Lakes supply $50 \%$ of annual fish consumption [2]. Large basins in Africa: Niger, Benue, Sokoto, Ouema, Shire, Barotse, Kafu flats, Massili \& Okarango have at least 100 species each [3]. However, Potential annual yield of small systems is about 2 million metric tons [4]. In some coastal cities: Zaire, Ethiopia, Keyna, Madagascar and Tazania freshwater fish are more important than marine fish and may contribute up to $90 \%$ of the total landings $[4,5]$. Nigerian inland water bodies are primarily used for fishing and the fisheries, is private sector driven and operates mainly in remote rural areas [6]. It contributes $86 \%$ of domestic fish production [7]. It is source of employment and provides income and nutrition for about 3 millions 
rural dwellers that depend on fish for livelihood. Nigeria could be self-sufficient in fish production and major exporter of fish if these water bodies are properly managed.

However, the fish yields of most inland waters are generally on the decline [8], which has been attributed to causes ranging from environmental degradation of the water bodies due to anthropogenic inputs from neighbouring communities and industries $[9,10]$. Impacted changes in water quality are reflected in the biotic community structure with the vulnerable dying, while the most sensitive species act as indicators of pollution [11-14] listed major industries responsible for water pollution in Nigeria to include petroleum, mining, wood, pulp, pharmaceuticals, textiles, plastics, iron and steel, brewing, distillery, fermentation, paints, beverages, food and agriculture. It was reported [15] fertilizer effluents from industrial city of Kano polluted Jakara reservoir. High levels of toxic heavy metals including copper, zinc, chromium, iron and manganese were detected $[16,17]$ in fish from Warwade Reservoir also in Kano. An increased in the pollution levels of the Cross River estuary by petroleum product spillage has been reported [18] which is a problem to the fishery industry.

To achieve management goals, it is necessary to know the changing pattern of fish populations in water bodies. This paper assesses the state of the fish community of the Cross River, before and after the establishment of wood processing industry at the shoreline of the upper portion of the river, in relation to species composition, food habit groups, length-weight relationship, fecundity and condition factor. It is expected that the information provided from the study will contribute to the formulation of management interventions for optimum utilization and sustainable socio-economic development of the Cross River.

\section{Materials and Methods}

\subsection{Study Site}

The study site is the Cross River, a floodplain river located at the South Eastern part of Nigeria (Figure 1) on Latitude $4^{\circ} 25^{\prime}-7^{\circ} 00^{\prime} \mathrm{N}$, Longitude $7^{\circ} 15^{\prime}-9^{\circ} 30^{\prime} \mathrm{E}$. It is bounded in the South by the Atlantic Ocean, East by the Republic of Cameroun, the Nigerian states of Benue in the North, Ebonyi and Abia in the West and Akwa Ibom; South West. Climate of the study area is defined by dry season and wet season. The wet season (April-October) is characterised by high precipitation $(3050 \mathrm{~mm} \pm 230$ $\mathrm{mm}$ ), while the dry season (November-March) is marked by low precipitation $(300 \mathrm{~mm} \pm 23 \mathrm{~mm})$. Mean annual temperature ranged from $15.5^{\circ} \mathrm{C} \pm 7.6^{\circ} \mathrm{C}$ (wet season) to $32.6^{\circ} \mathrm{C} \pm 5.4^{\circ} \mathrm{C}$ (dry season). For the purpose of this study three sampling sites were selected along the length of the river, with one site randomly selected in each of the following reaches; upriver, middle river and downriver. The effluent point of a wood processing industry was located at the shoreline of the upper portion of the river which was covered by savanna grassland and $3 \mathrm{~km}$ from the river source with rocky, gravel and sandy substratum. The middle river was $100 \mathrm{~km}$ from river source with rocky substratum and shoreline sparsely shaded by forest and savanna grassland. Downriver had a muddy substratum and opens up into the Cross River estuary, with shoreline thickly shaded with rainforest.

\subsection{Ichthyofaunal Sampling}

The ichthyofuana of the river was sampled at the same time of physico-chemical sampling in all the reaches using variety of fishing gears which included; gill net (22 - 76 $\mathrm{mm}$ stretched mesh size), seine net (10mm stretched mesh size) and cast net (10 mm stretched mesh). On each occasion sampling was between 09.00 and $12.00 \mathrm{am}$. Genus and species identifications was carried out for the Cyprinids [20]; Bagrids [21], Clariidae [22]; Clupeidae and Mugilidae [23]. Species abundance of each reach was presented as a numerical contribution by each species. This was determined by calculating the percentage each species represented of the total catch for each reach based on the number of species.

\subsection{Length-Weight Relationship And Condition Factor}

Fish weights were measured to nearest $0.1 \mathrm{~g}$ and total length (TL) to nearest $1 \mathrm{~mm}$. Length- weight relationship (LWR) was estimated from the equation; $W=a L^{b}$ [24] and was $\operatorname{logarithmically~transformed~into~} \log W=\log a+$ $b \log L . W=$ weight of fish in grams, $L=$ total length of fish in centimeters, $a=$ constant of proportionality and $b$ $=$ allometry coefficient. The parameters $a$ and $b$ are estimated by method of least squares regression [25] using the log trans -formed data. The condition factor was determined using the expression [26] as $K=W \cdot 100 / \mathrm{L}^{3} \cdot K=$ Condition factor, $W=$ Total body weight, $L=$ Total length.

\subsection{Gut Content Analysis.}

To determine changes in food habit groups of fishes samples were transported to the laboratory under ice to minimize post mortem changes. Each specimen was measured for total length $(\mathrm{cm})$ and weight $(\mathrm{g})$ with date, time and location [27]. Fish samples were preserved in deep freezers at $-10^{\circ} \mathrm{C}$. The fish were later dissected, gutted and preserved in $4 \%$ formalin for subsequent analysis. Each stomach contents were emptied into a Petri-dish and observed under a binocular microscope. Individual 


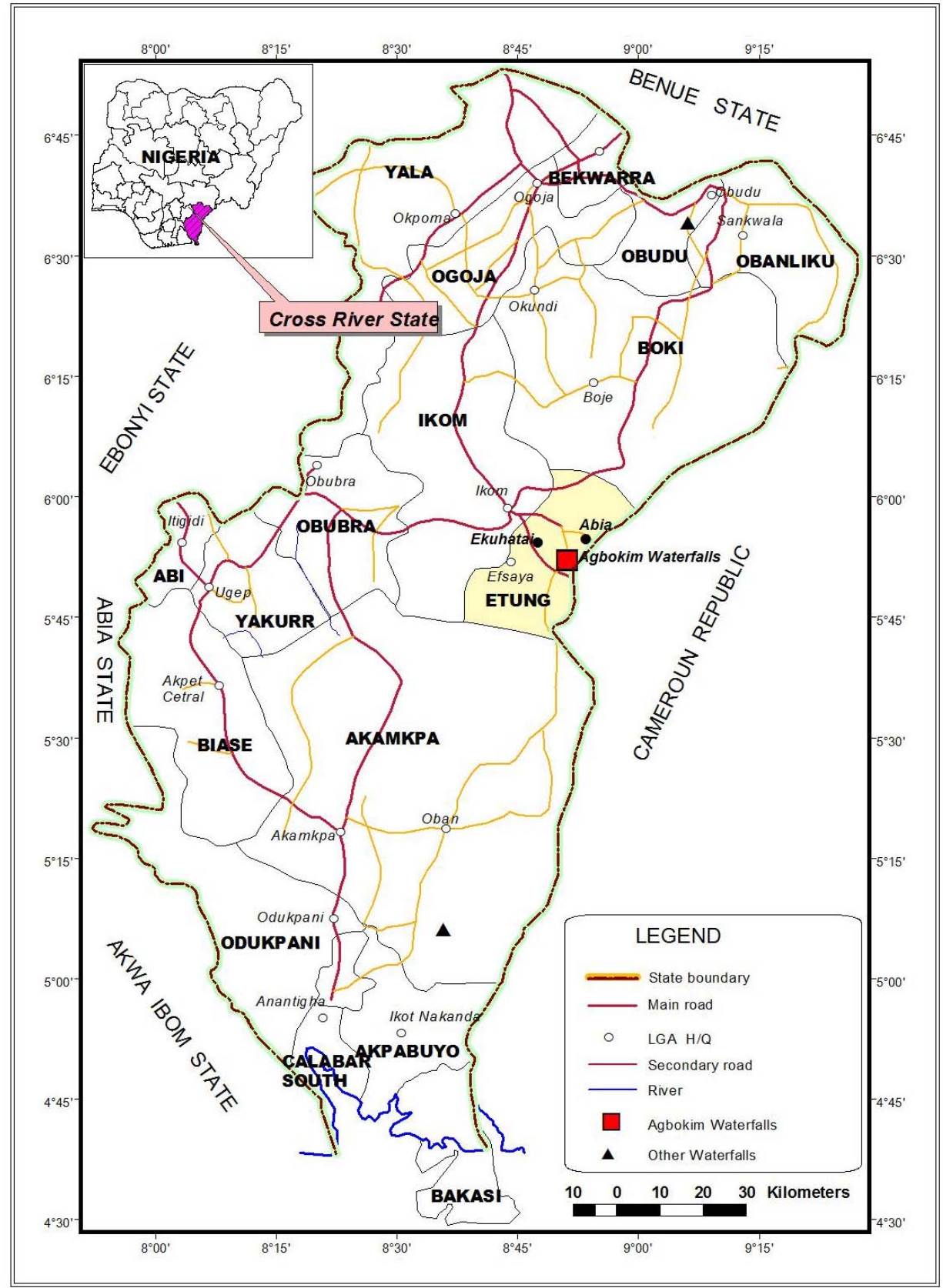

Figure 1. Map of Cross River State showing study area.

food items were identified to the lowest taxonomic level and the entire content analysed using frequency of occurrence [26].

\subsection{Fecundity, Gonadosomatic Index, Egg Size}

Analysis of fecundity was limited to the peak spawning period (May-July) and only ripe female fish (494) were used for the estimation. Ovaries were excised from body cavity of each fish and preserved in Gilson fluid [28]. Only the largest eggs $(0.5-3.0 \mathrm{~mm})$ in each sample were used for fecundity estimation. Fecundity was calculated by multiplying the total weight of eggs by the number of eggs per gram weight [29].

Gonad cycle was determined from gonado - somatic index $\left(I_{G}\right)$ expressed according to De Vlaming et al. [30] as:

$$
I_{G}=\frac{\text { Gonad weight } \times 100}{\text { Body weight }}
$$


$I_{G}$ was used to follow seasonal changes in the gonads.

Egg diameter was measured from samples collected from different parts of the ovary (anterior, middle and posterior parts) using ocular micrometer mounted on a binocular microscope Imevbore [31].

\subsection{Data treatment and analysis}

The mean and standard deviation of each of the physico-chemical parameters were calculated. Analysis of variance (ANOVA) was used to test for statistical differences between the means of the physical and chemical parameters of the sampling years. Presence - absence data (quantitative scale issue) was used as a measure of community composition. Based on the information obtained, fish species were qualitatively categorized as follows:

Disappeared: Species not sampled in all subsequent studies after first appearance.

Declined: Species that are either absent or present in relatively low numbers or observed in commercial catches but not encountered in later years.

Appeared: Species not present in all pre-impoundment and post-impoundment studies except after establishment of wood processing industry.
Valuable: Species present in the river and contributing at least $10 \%$ to sampled fish in terms of weight and numbers.

Permanent: Species present in all pre-impoundment and post-impoundment studies conducted on the river.

\section{Results}

\subsection{Fish Species Composition and Status}

Table 1 presents all fish species identified in both pre-industry (2000) and post-industry (2001-2006) establishment studies undertaken on the Cross river. Important freshwater species categorised as 'disappeared' include Sarotherodon melanopleura, H.fasciatus, (Cichlidae); Mormyrus rume, Mormyrus tapirus, M. anguilloides, $\mathrm{P}$. bovei, G. cyprinoides, G. senegalensis, H. occidentalis, M. isidori (Mormyridae); Hydrocyanus vittatus, Bricynus macrolepidotus, Bricynus chaperi (Characidae); Polypterus senegalensis, Polypterus endlicheri, Calamoichthys calabaricus (Polypteridae) (Table 2). while three species namely Synodontis violaceus (Mochokidae); Chrysichthys maurus (Bagridae) and Tilapia monody (Cichlidae) appeared in the Cross River for the first time. These species are grouped as 'appeared' in this study.

Table 1. List of species identified in Cross River during the 13 years of study.

\begin{tabular}{|c|c|c|c|c|c|}
\hline Family/species & 1997 & 2000 & 2003 & 2006 & 2010 \\
\hline \multicolumn{6}{|l|}{ Cichlidae } \\
\hline Oreochromis niloticus & $* * *$ & $* * *$ & $*$ & $*$ & $* *$ \\
\hline Tilapia galilaeus & $* *$ & $* *$ & * & $*$ & $* *$ \\
\hline Tilapia mariae & $*$ & $*$ & $*$ & $*$ & $*$ \\
\hline Tilapia zilli & $* *$ & $* *$ & $*$ & $*$ & $*$ \\
\hline Tilapia monody & & & $*$ & & $*$ \\
\hline Sarotherodon galilaeus & $* *$ & $* *$ & * & $*$ & $*$ \\
\hline Sarotherodon melanopleura & $*$ & $*$ & $*$ & & \\
\hline Sarotherodon melanotheron & $* *$ & $*$ & $*$ & $*$ & $*$ \\
\hline Hemichromis fasciatus & $*$ & $*$ & & & $*$ \\
\hline Hemichromis bimaculatus & $*$ & $*$ & & $*$ & $*$ \\
\hline \multicolumn{6}{|l|}{ Protopteridae } \\
\hline Protopterus annectens & $* *$ & $* *$ & & & $*$ \\
\hline \multicolumn{6}{|l|}{ Polypteridae } \\
\hline Polypterus senegalus & $*$ & & & & $*$ \\
\hline Polypterus endlicheri & $*$ & $*$ & & & \\
\hline Calamoichthys calabaricus & $* *$ & $* *$ & & & \\
\hline \multicolumn{6}{|l|}{ Denticeptidae } \\
\hline Denticeps clupeoides & $* *$ & $*$ & & & $*$ \\
\hline
\end{tabular}




\begin{tabular}{|c|c|c|c|c|c|}
\hline \multicolumn{6}{|l|}{ Distichodontidae } \\
\hline Distichodus rostratus & $*$ & $*$ & * & * & * \\
\hline \multicolumn{6}{|l|}{ Clupeidae } \\
\hline Cynothrissa $\mathrm{sp}$ & $* *$ & $* *$ & $*$ & * & $*$ \\
\hline Pellonula vorax & $*$ & $* *$ & & & \\
\hline \multicolumn{6}{|l|}{ Osteoglossidae } \\
\hline Heterotis niloticus & $* *$ & $* *$ & $*$ & $*$ & ** \\
\hline \multicolumn{6}{|l|}{ Mormyridae } \\
\hline Mormyrus rume & $* *$ & $* *$ & $*$ & & $* *$ \\
\hline Mormyrus deliciosus & $* *$ & $* *$ & $*$ & $*$ & * \\
\hline Mormyrus tapirus & $*$ & $*$ & & $*$ & * \\
\hline Mormyrops anguilloides & $*$ & $*$ & & & \\
\hline Petrocephalus bovei & $* *$ & $* *$ & & & $* *$ \\
\hline Petrocephalus. Ansorgii & $* *$ & $* *$ & $*$ & * & $*$ \\
\hline Gnathonemus cyprinoides & $*$ & $*$ & & & $*$ \\
\hline Gnathonemus senegalensis & & $*$ & & & \\
\hline Hyperopisus occidentalis & $*$ & * & $*$ & & \\
\hline Marcusenius isidori & $*$ & & & & $*$ \\
\hline Marcusenius psittacus & & & & & $*$ \\
\hline \multicolumn{6}{|l|}{ Hepsetidae } \\
\hline Hepsetus odoe & $*$ & $* *$ & & & $*$ \\
\hline \multicolumn{6}{|l|}{ Characidae } \\
\hline Hydrocyanus vittatus & * & $*$ & & & * \\
\hline Bricynus nurse & $* *$ & $* *$ & $*$ & * & * \\
\hline Brycinus chaperi & $* *$ & $*$ & & & \\
\hline Bricynus macrolepidotus & $*$ & $* *$ & $*$ & & $*$ \\
\hline \multicolumn{6}{|l|}{ Clariidae } \\
\hline Clarias anguillaris & $* * *$ & $* * *$ & $* *$ & $* *$ & $* *$ \\
\hline Clarias cameronensis & $* *$ & $* *$ & ** & $* *$ & $* *$ \\
\hline Clarias gariepinus & $* *$ & $* *$ & $* *$ & $* *$ & $* *$ \\
\hline Clarias pachynema & $*$ & $*$ & & & \\
\hline Clarias aboinensis & $*$ & $*$ & $*$ & $*$ & $*$ \\
\hline Heterobrachus longifilis & $* *$ & $* *$ & $*$ & $*$ & * \\
\hline Heterobranchus bidorsalis & $*$ & $*$ & $*$ & * & $*$ \\
\hline \multicolumn{6}{|l|}{ Bagridae } \\
\hline Bagrus docmak & $*$ & $*$ & & $*$ & $*$ \\
\hline Bagrus bayad & $* *$ & $* *$ & $*$ & $*$ & $*$ \\
\hline Chrysichthys auratus & $* * *$ & $* * *$ & * & $*$ & $* *$ \\
\hline Chrysichthys nigrodigitatus & $* * *$ & $* * *$ & $*$ & $*$ & ** \\
\hline Chrysichthys walker & $*$ & $*$ & $*$ & $*$ & $*$ \\
\hline
\end{tabular}




\begin{tabular}{|c|c|c|c|c|c|}
\hline Chrysichthys furcatus & $*$ & $*$ & $*$ & $*$ & $*$ \\
\hline Chrysichthys maurus & & & $*$ & $*$ & $*$ \\
\hline Chrysichthys filamentosus & $* *$ & $* *$ & & & $*$ \\
\hline \multicolumn{6}{|l|}{ Mochokidae } \\
\hline Synodontis membranaceus & $* * *$ & $* *$ & & & * \\
\hline Synodontis omias & $*$ & $*$ & $*$ & & \\
\hline Synodontis rabbianus & $*$ & $*$ & $*$ & & $*$ \\
\hline Synodontis nigrita & $*$ & $*$ & $*$ & * & $*$ \\
\hline Synodontis schall & $* * *$ & $* * *$ & & & ** \\
\hline Synodontis obesus & $* *$ & $* *$ & $*$ & $*$ & * \\
\hline Synodontis courteti & $*$ & $*$ & $*$ & & \\
\hline Synodontis eupterus & $*$ & $*$ & & & * \\
\hline Synodontis gambiensis & & & & & $*$ \\
\hline Synodontis ocellifer & $*$ & $*$ & & & \\
\hline Synodontis velifer & $*$ & $*$ & & & \\
\hline Synodontis sorex & $*$ & $*$ & & & $*$ \\
\hline Synodontis violaceus & & & $*$ & $*$ & $*$ \\
\hline \multicolumn{6}{|l|}{ Malapteruridae } \\
\hline Malapterus electricus & $*$ & $*$ & $*$ & * & * \\
\hline \multicolumn{6}{|l|}{ Cyprinidae } \\
\hline Barbus occidentalis & $* *$ & $* *$ & $*$ & $*$ & $*$ \\
\hline Barilius senegalensis & $*$ & $*$ & $*$ & & \\
\hline Barbus macrops & $*$ & & & & \\
\hline Barilius loati & $*$ & $*$ & & & \\
\hline Labeo coubie & * & $*$ & $*$ & $*$ & $*$ \\
\hline Labeo senegalensis & $*$ & $*$ & $*$ & $*$ & $*$ \\
\hline Labeo parvus & $*$ & $*$ & $*$ & $*$ & $*$ \\
\hline \multicolumn{6}{|l|}{ Schilbeidae } \\
\hline Eutropius niloticus & $* *$ & $* *$ & $*$ & $*$ & * \\
\hline Eutropius micropogon & $* *$ & $* *$ & $*$ & $*$ & $*$ \\
\hline Schilbe mystus & $* *$ & $*$ & $*$ & $*$ & $*$ \\
\hline Schilbe intermedius & $*$ & $*$ & & & * \\
\hline \multicolumn{6}{|l|}{ Charanidae } \\
\hline Parachanna obscura & * & $*$ & $*$ & $*$ & * \\
\hline \multicolumn{6}{|l|}{ Centropomidae } \\
\hline Lates niloticus & $*$ & $*$ & $*$ & & $*$ \\
\hline \multicolumn{6}{|l|}{ Icthyoboridae } \\
\hline Phago loricatus & * & * & & & \\
\hline
\end{tabular}

*: Scarce, **: Common, ***: Abundant. 
Table 2. Qualitative description of current status of fish species identified in Cross River during period of study.

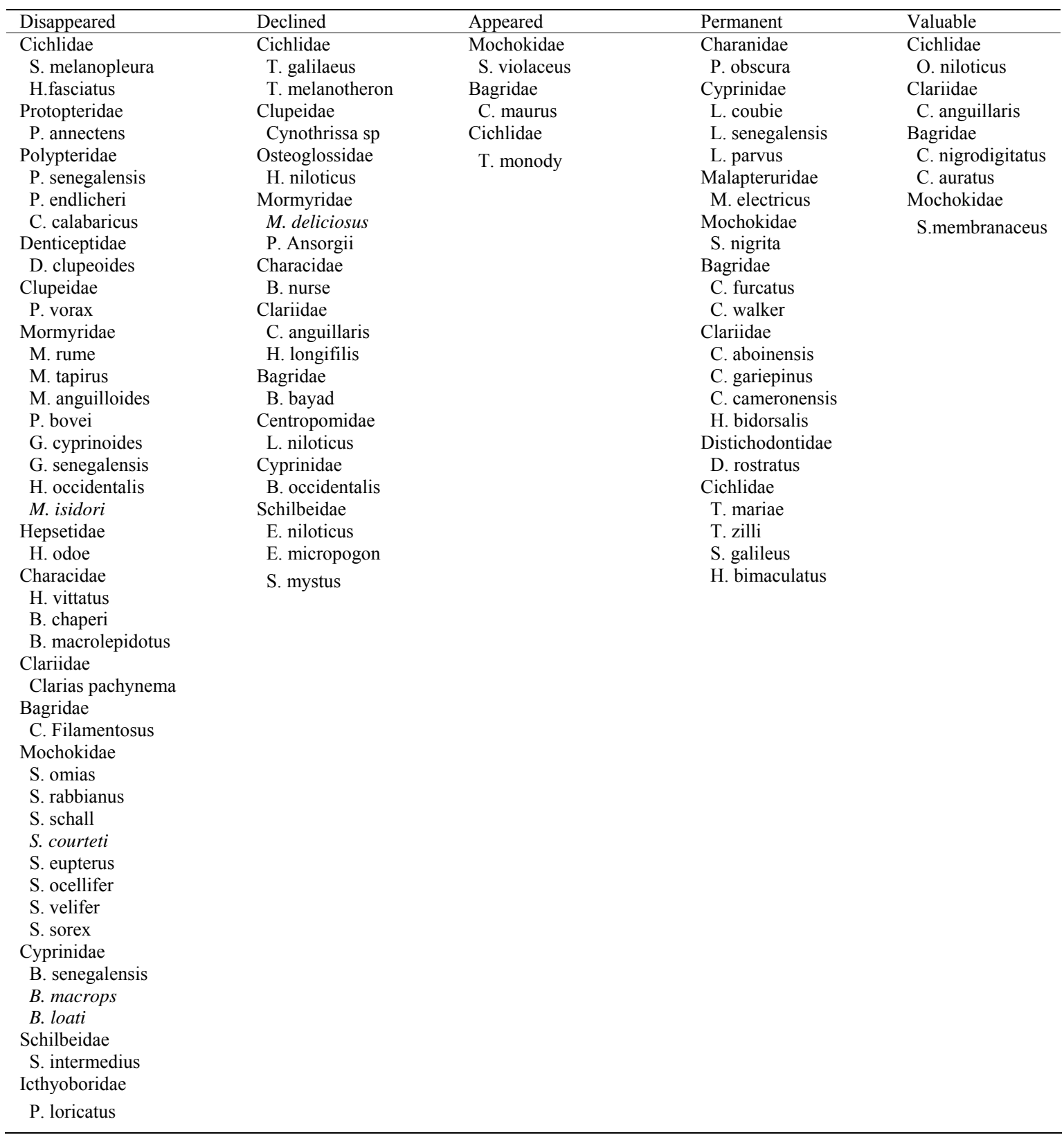

Species grouped as 'declined' include Tilapia galilaeus, Tilapia melanotheron (Cichlidae); Cynothrissa sp (Clupeidae); H. niloticus (Osteoglossidae), Mormyrus deliciosus, Petrocephalus ansorgii (Mormyridae); Bricynus nurse (Characidae); Heterobranchus longifilis (Clariidae) Bagrus bayad, Synodontis obesus (Mochokidae); Barbus occidentalis (Cyprinidae); Eutropius niloticus, Eutropius macropogon (schilbeidae). 5 fish species which have been grouped as 'valuable' in the Cross River are Oreochromis niloticus (Cichlidae), Clarias anguillaris (Clariidae), C. auratus, C. nigrodigitatus (Bagridae); and Syno- dontis membranaceus (Mochokidae). Chysichthys furcatus, Chrysichthys walker (Bagridae); Clarias aboinensis, Clarias gariepinuss (Clariidae); Tilapia mariae (Cichlidae) were grouped as permanent.

\subsection{Changes in the Length-Weight Relationship and Condition Factor}

Before establishment of wood processing industry distribution of values of allometry coefficient (b) ranged between 1.2 and 3.65 and mean b-value for all the species was $2.64 \pm 0.32$ and the mode; 3.5 (Figure 2). These values diminished considerably after six years to a range 
from $1.2-2.2$, mean value of $1.82 \pm 0.23$ and mode of 2.0 . The distribution of $b$ values after six years deviate significantly from the cube value $(b=3, P>0.05)$. The condition factor of the fish sampled varied from 0.53 to 1.30 with mean value of $0.772 \pm 0.12$, mode; 1.20 and median; 0.72 to a range between 0.22 and 0.62 with mean $0.45 \pm$ 0.06 , mode; 0.55 and median 0.40 (Figure 3).

\subsection{Changes in Food Habit Groups of Fishes}

Analysis of frequency of occurrence of food objects in the different fish families showed that intake of phytoplankton, fish fry, insects, crustaceans and mollusk declined six years after the establishment of the industry (Table 3). Ingestion of detritus, seeds, fish parts and macrophytes increased considerably.

\subsection{Distribution of Major Food Items in the Study Area}

Distribution of four selected fish species and their prey indicated that these fish were predominantly located in a few specific areas six years after the establishment of the industry (Table 4). Nymphaea and spirogyra are the main diet of $O$. niloticus in the pre-industry era (2000) and it was found that these food items were distributed in reaches II and I respectively with a percentage occurrence of between $0.1 \%-10.0 \%$ for spirogyra and $0.1 \%$ $20.0 \%$ for nymphaea. Meanwhile, for $H$. niloticus, Reach I and II had the highest abundance of spirogyra and nymphaea respectively with the percent abundance of 0.1 - $20.0 \%$ for spyrogyra and $0.1 \%-10.0 \%$ for Nymphaea. Pellonula sp and detritus were the main diet of C. gariepinus and the abundance of this diet was higher in Reach I and III respectively. C. nigrodigitatus consumed mainly Macrobrachium sp and Nertina sp distributed predominantly in Reach II and III respectively. However, nine years after, major food items in the diet of all the main fish species were detritus and macrophytes particularly in Reach I.

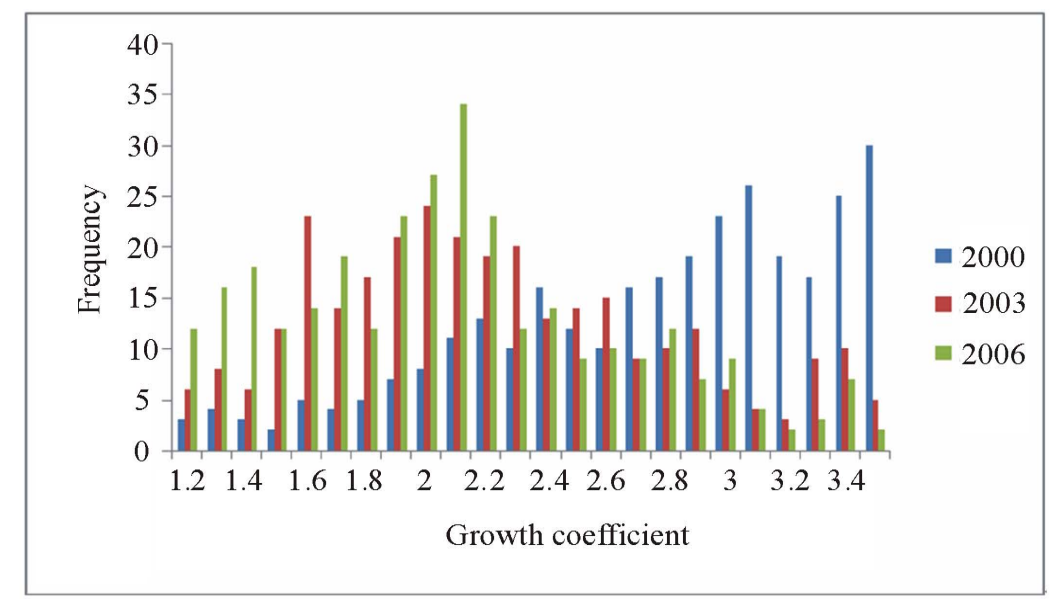

Figure 2. Changes in the frequency of the mean growth coefficient of the fish community.

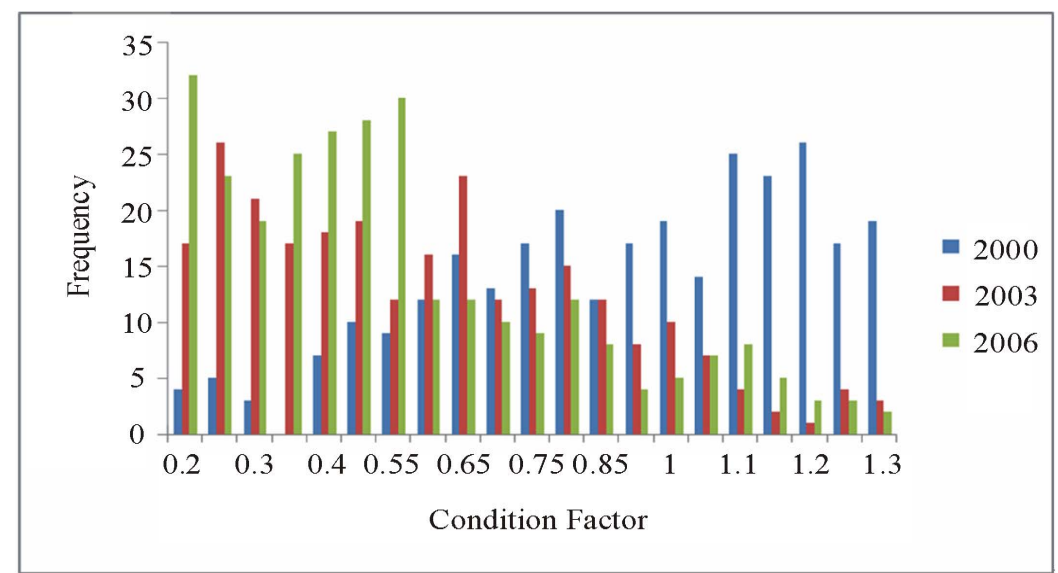

Figure 3. Changes in the frequency of the mean condition factor of the fish community during six years. 
Table 3. Changes in the food habits in the different fish families.

\begin{tabular}{|c|c|c|c|c|c|}
\hline \multirow{2}{*}{ Fish families } & \multicolumn{5}{|c|}{ Feeding habits during pre and post establishment of wood industry } \\
\hline & 1997 & 2000 & 2003 & 2006 & 2010 \\
\hline \multirow[t]{2}{*}{ Cichlidae } & \multirow[t]{2}{*}{ Phytoplankton $43 \%$} & Phytoplankton $15 \%$ & Phytoplankton 5\% & Macrophytes $33 \%$ & Phytoplankton $29 \%$ \\
\hline & & Macrophytes $28 \%$ & Macrophytes 34\% & Detritus $21 \%$ & Macrophytes $8 \%$ \\
\hline \multirow[t]{2}{*}{ Cyprinidae } & \multirow[t]{2}{*}{ Phytoplankton $24 \%$} & Phytoplankton $10 \%$ & Seeds $37 \%$ & Seeds $23 \%$ & Phytoplankton $17 \%$ \\
\hline & & Seeds $34 \%$ & Detritus $40 \%$ & Detritus $44 \%$ & Detritus $32 \%$ \\
\hline \multirow[t]{3}{*}{ Bagridae } & Mollusk 33\% & Fish parts $38 \%$ & Fish parts $40 \%$ & Fish parts $34 \%$ & Molluses 10\% \\
\hline & \multirow[t]{2}{*}{ Crustacea $25 \%$} & Mollusk 15\% & Detritus $32 \%$ & Detritus 44\% & Fish fry $39 \%$ \\
\hline & & Crustacean $8 \%$ & & & Crustacean $18 \%$ \\
\hline \multirow[t]{3}{*}{ Clariidae } & \multirow[t]{3}{*}{ Fish fry $34 \%$} & Fish fry $10 \%$ & Fish parts $39 \%$ & Fish parts $31 \%$ & Fish fry $28 \%$ \\
\hline & & Fishparts $29 \%$ & Macrophytes 21\% & Macrophytes 33\% & Detritus $18 \%$ \\
\hline & & & Detritus 23\% & Worms $10 \%$ & \\
\hline \multirow[t]{3}{*}{ Schilbeidae } & \multirow[t]{3}{*}{ Detritus $41 \%$} & \multirow[t]{3}{*}{ Detritus 51\% } & \multirow[t]{3}{*}{ Detritus $45 \%$} & \multirow[t]{3}{*}{ Detritus $40 \%$} & Detritus $34 \%$ \\
\hline & & & & & Insects $24 \%$ \\
\hline & & & & & Fish fry $12 \%$ \\
\hline \multirow[t]{2}{*}{ Mormyridae } & \multirow[t]{2}{*}{ Detritus $22 \%$} & \multirow[t]{2}{*}{ Detritus $32 \%$} & \multirow[t]{2}{*}{ Detritus $44 \%$} & Detritus $39 \%$ & Detritus 24\% \\
\hline & & & & Seeds $23 \%$ & Worms 18\% \\
\hline \multirow[t]{2}{*}{ Clupeidae } & \multirow[t]{2}{*}{ Insects $20 \%$} & Insects $6 \%$ & \multirow[t]{2}{*}{ Detritus 23\% } & \multirow[t]{2}{*}{ Detritus 34\% } & Insects $28 \%$ \\
\hline & & Worms 21\% & & & Fish fry $20 \%$ \\
\hline \multirow[t]{3}{*}{ Osteoglossidae } & Insects $15 \%$ & Insects $8 \%$ & Seeds $40 \%$ & Seeds $32 \%$ & Seeds $12 \%$ \\
\hline & \multirow[t]{2}{*}{ Macrophytes 13\% } & \multirow[t]{2}{*}{ Macrophytes 24\% } & \multirow[t]{2}{*}{ Macrophytes $21 \%$} & \multirow[t]{2}{*}{ Macrophytes $28 \%$} & Insects $27 \%$ \\
\hline & & & & & Macrophytes 23\% \\
\hline \multirow[t]{2}{*}{ Distichodontidae } & \multirow[t]{2}{*}{ Insects $12 \%$} & 1 nsects $5 \%$ & \multirow[t]{2}{*}{ Detritus $32 \%$} & \multirow[t]{2}{*}{ Detritus $42 \%$} & Detritus $12 \%$ \\
\hline & & Detritus $24 \%$ & & & Insects $18 \%$ \\
\hline \multirow[t]{2}{*}{ Mokochidae } & Insects $10 \%$ & Insects $3 \%$ & Detritus 25\% & Detritus 31\% & Insects $25 \%$ \\
\hline & & Detritus 23\% & & & \\
\hline
\end{tabular}

Table 4. Distribution of dominant preys with reaches (in parenthesis). Or: Oreochromis niloticus, Cl: Clarias gariepinus, Ch: Chrysichthys nigrodigitatus, He: Heterotis niloticus, La: Labeo coubie, Br: Bricynus sp.

\begin{tabular}{|c|c|c|c|c|c|c|}
\hline Fish species & Or & $\mathrm{Cl}$ & $\mathrm{Ch}$ & $\mathrm{He}$ & $\mathrm{La}$ & $\mathrm{Br}$ \\
\hline No of fish & 220 & 190 & 201 & 118 & 136 & 343 \\
\hline Empty stomach & 0 & & 0 & 12 & 171 & \\
\hline \multicolumn{7}{|l|}{ Food items } \\
\hline \multicolumn{7}{|l|}{ Crustacea } \\
\hline Macrobrachium & & $\begin{array}{l}0.1-20.0(\mathrm{III}) \\
2006\end{array}$ & $\begin{array}{l}0.1-10.0(\mathrm{II}) \\
2000\end{array}$ & & & \\
\hline \multicolumn{7}{|l|}{ Insecta } \\
\hline Dipteran adult & & $0.1-20.0$ & $\begin{array}{l}0.1-20.0(\mathrm{I}) \\
2006\end{array}$ & $\begin{array}{l}0.1-20.0(\mathrm{I}) \\
2000\end{array}$ & $0.1-10.0(\mathrm{III})$ & \\
\hline \multicolumn{7}{|l|}{ Molluscs } \\
\hline Nertina sp & & & $\begin{array}{l}0.1-20.0(\mathrm{III}) \\
2000\end{array}$ & & & \\
\hline \multicolumn{7}{|l|}{ Fish (prey) } \\
\hline Pellonula sp & & $\begin{array}{l}0.1-20.0(\mathrm{I}) \\
2000\end{array}$ & $\begin{array}{l}0.1-20.0(\mathrm{I}) \\
2006\end{array}$ & & & \\
\hline \multicolumn{7}{|l|}{ Plants } \\
\hline Nymphaea & $\begin{array}{l}0.1-20.0(\mathrm{II}) \\
2000\end{array}$ & $\begin{array}{l}0.1-20.0(\mathrm{I}) \\
2006\end{array}$ & $\begin{array}{l}0.0-20.0(\mathrm{I}) \\
2006\end{array}$ & $\begin{array}{l}0.1-20.0(\mathrm{I}) \\
2000\end{array}$ & $0.1-10.0(\mathrm{II})$ & \\
\hline Spirogyra & $\begin{array}{l}0.1-10.0(\mathrm{I}) \\
2000\end{array}$ & & & $\begin{array}{l}0.1-10.0(\mathrm{II}) \\
2000\end{array}$ & & \\
\hline Detritus & $\begin{array}{l}0.1-20.0(\mathrm{I}) \\
2006\end{array}$ & $\begin{array}{l}0.1-10.0(\mathrm{I}) \\
2006\end{array}$ & $\begin{array}{l}0.1-20.0(\mathrm{I}-\mathrm{III}) \\
2006\end{array}$ & $\begin{array}{l}0.1-20.0(\mathrm{I}) \\
2006\end{array}$ & & \\
\hline
\end{tabular}

\subsection{Fecundity, Egg Size and Gonadosomatic Index}

5234 eggs, mode 12500 and median 58345 in 2000 to mean value $23122 \pm 232$ eggs, mode 2500 and median 20349 in 2006 (Figure 4), gonadosomatic index from 20.5

Distribution of fecundity values varied from $56012 \pm \quad \pm 3.2$ eggs, mode $19.1 \pm 2.2$ and median 21.4 to values of 
$12.4 \pm 2.3$, mode 4.5 and median 9.5 (Figure 5) and egg size from mean value; $1.82 \mathrm{~mm} \pm 0.07 \mathrm{~mm}$, mode 2.2 , and median; 1.8 to values of $0.8 \mathrm{~mm} \pm 0.04 \mathrm{~mm}$, mode; 1.3 and median 1.1 (Figure 6) and respectively.

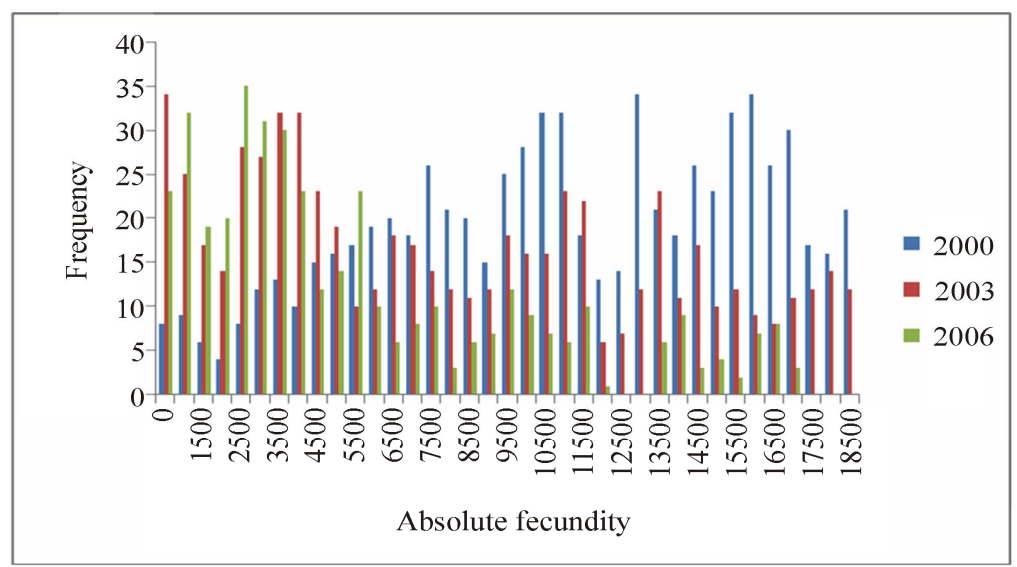

Figure 4. Changes in the frequency distribution of fecundity of the fish species during the six years.

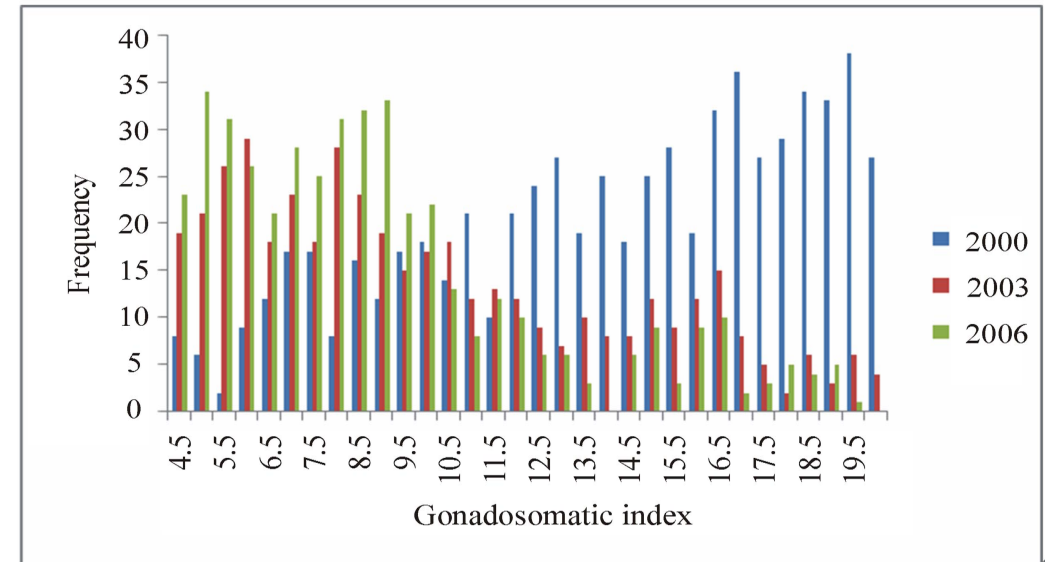

Figure 5. Changes in the frequency distribution of the gonadosomatic index of fish species during the six years.

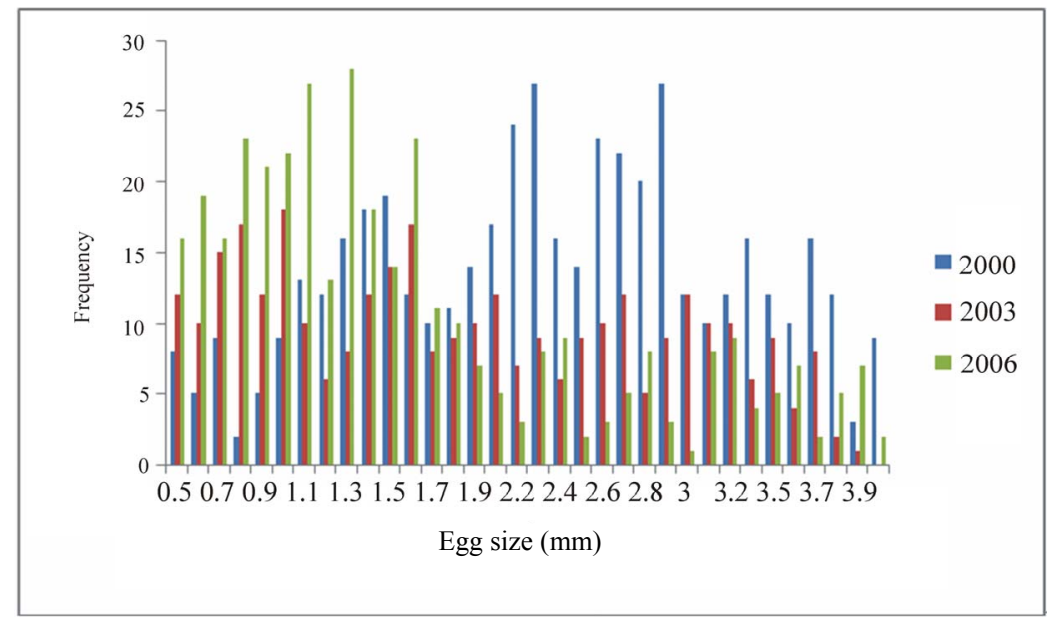

Figure 6. Changes in the frequency distribution of egg sizes of fish species during the six years. 


\section{Discussion}

\subsection{Changes in Fish Species Composition and Status}

The list of fishes shown in this study is the current fish assemblage in the Cross River as a result of restructuring of the communities that previously occupied the Cross River and its floodplains by effluent from an associated wood industry and the recovery effect after closing down the industry by law. Disappearance of some components of the original fish community and alterations in the abundance of some species has resulted in the current fish assemblage. It has been reported [32] that wood factory waste are toxic when they cover the bottoms of water bodies, they decrease the amount of $\mathrm{pH}$ and dissolved oxygen. The lower $\mathrm{pH}$ range could be as a result of high acid content of organic effluents from the wood processing factory located upriver. This could lead to the disintegration of the river ecosystem resulting in the decline or disappearance of those species whose life cycles have been disrupted by these changes. The fish community of the Cross River appears to have been gradually transformed from those adapted to unpolluted river conditions to those adapted to polluted conditions. It was shown that the disintegration of river ecosystem has led to a reduction in the number of fish species in the world's watersheds [33].

Species which were predominant one year before establishment of wood processing industry appear to have been affected by changes in the physical and chemical conditions of the water following effluents and this had led to species either disappearing or becoming reduced considerably in terms of numbers. The once abundant but now scarce fish species give indication of changes in fish populations and relative abundance in Cross River. This observation could result from the fact that these species experienced the greatest natural mortality during the early years of establishing the wood processing industry because most of them were at top level of the food chain resulting in a faster decline in their abundance.

In the different years fish species sampled were 72 (1997), 70 (2000), 46 (2003), 36 (2006) and 62 (2010) indicating that the fish species composition of the Cross River was undergoing changes. This observation could be attributed to the disappearance of fish species from the river due to disintegration of the river ecosystem and alteration of living conditions after establishment of industry. Fish species whose life cycles have been particularly disrupted by the establishment of industry are unable to adapt to new conditions and may disappear from the community [34]. The disappearance of fish species from the Cross River within the short time still raises conservation concerns, especially when as many as thirty six even species were involved.

\subsection{Changes in Relative Abundance of Fish Species}

Many fish species adapt to environmental changes in water bodies to varying degrees and continue to exist at changed abundance [35]. Whereas some species have maintained their populations at about the same level when compared with the pre-industry period, others have declined while others have increased in their numbers as a result of favourable environmental changes. Changes in relative abundance are underpinned by alteration of the existing ecological and biophysical processes after establishment of industry such as the obvious reduction in the population of invertebrates and the invasion of aquatic weeds upriver close to effluent point. The industrial effluents created new conditions that were favourable to herbivorous fish species and detritus species which responded with increase in numbers of individuals and total biomass [35-38]. Some of these fish species include Labeo coubie, Clarias aboinensis, Clarias cameronensis, Tilapia mariae, Distodontus rostratus, Heterobranchus bidorsalis and Malapterurus electricus. The conditions created in the Cross river by the industrial effluents appeared to have been unfavourable to some fish species such as $T$ melonotheron, $H$ niloticus, Cynotrissa $s p, M$ deliciosus, P ansorgii, B. occidentalis and B. Bayad, Lates niloticus, Labeo spp and Bagrus spp. resulting in their decline. The effluents could have contaminated food supply and their spawning grounds. On the other hand, Cichlidae (Oreochromis niloticus) Bagridae (mainly (Chrysichthys nigrodigitatus and C. auratus), Clariidae (Clarias anguillaris) and Mochokidae (S. Schall and S. membranaceus) have currently emerged as most important. Notwithstanding the general decline in relative abundance of Bagrids, however, Chrysichthys nigrodigitatus has continued to remain most abundant species in terms of number even after the period of existence of the wood processing industry. The reason for the extreme proliferation of this species is not clear despite a common phenomenon in tropical water bodies that no one species dominates the fishery for a long time hence it is expected that over time other species apart from Chrysichthys nigrodigitatus are suppose to dominate the Cross River fish community. In terms of numbers, Cichlids have declined slightly in relative abundance compared with pre-industry figures. Of the Cichlids in the Cross River, Tilapia melanotheron was not doing well in relative abundance compared with $T$. mariae over the period of existence of the industry, a situation which is similar to what pertained in the Weija Reservoir after 28 years of impoundment [39]. 


\subsection{Changes in the Length-Weight Relationship and Condition Factor}

Seventy six percent of the species presented in this study exhibited a trend of isometric growth $(b=3)$ depicting dimensional equality before the establishment of wood processing industry [24]. This trend contrast greatly from the species during the existence of the industry where the pattern indicated an acute negative allometry. This may be attributed to the change in ecological parameters at the freshwater environment after establishment of the industry in which these species have carved their ideal niche. The riverine environment is characterized mainly by high oxygen content, low salinity, high nutrient content and higher productivity in contrast to the contaminated post-industry condition [40]. To counter the scarcity of nutritional resources at post-industry establishment somatic growth is less important and energy is diverted to reproductive processes [41]. The general trend of negative allometry exhibited by some most fish species after establishment of industry compared to the isometry observed in most of the species in the study area before existence of industry may be regarded as floodplain adaptations to survive in the polluted river.

The fact that $65 \%$ of the entire 78 species examined had condition factor above mean and that the overall mean condition factor did not significantly deviate from the value of 1.0 showed that the majority of the fish in the populations of Cross River inland wetlands were in good condition before the establishment of wood processing industry, thus justifying the dimensional equality of their growth pattern. The high condition factor of the fish species in the river pre-industry era is an indication of abundant food. Low condition factor showed during existence of industry indicates that food resources had diminished.

\subsection{Changes in Food Habit Groups of Fishes}

Though herbivores and detritivores were the least important in terms of weight and numbers in pre industry establishment studies undertaken in the Cross River, they have currently increased significantly in numbers and weight becoming the most important in terms of numbers. From reports of studies undertaken after establishment of industry, benthic carnivores have declined in their importance probably due to contamination by effluents that have reduced food resources and spawning grounds for benthic and pelagic invertebrates and fish preys. Further downstream in Reaches II and III, however, benthic omnivores have continued in their importance and have maintained their dominance in the Cross River. The omnivores together (i.e. both semi pelagic and benthic om- nivores) have, however, become most important in the Cross River after the existence of the industry.

Importance of herbivores after six years of the existence of the industry has increased considerably compared with the period before the establishment of industry, possibly due to declining food sources.

The composition of piscivores after six years of establishment of wood industry declined compared with one year pre industry existence. The general decline in the importance of piscivores in the Cross River during the period of existence of industry could be attributed partly to the disappearance of some piscivorous fishes as well as their restricted distribution due to decline of fish preys and their preference for unpolluted river conditions which have reduced over the period of existence of the industry. Clarias gariepinus has maintained its importance as a "fish-eating fish" in the Cross River during the period of existence of wood industry whereas Hemichromis fasciatus has disappeared and Clarias anguillaris has declined in abundance. The wider food spectrum exhibited by $C$. anguillaris , C. nigrodigitatus and $O$. niloticus revealed trophic flexibility [42]. The ecological advantage of this is that it enables a fish to switch from one category of food to another in response to fluctuation in their abundance. Another advantage is the ability of the species to utilize many different food objects effectively and this probably accounts for their higher abundance in the study area during pre-industry period $[43,44]$.

The fact that detritus dominated the gut contents of the freshwater species in the study area during the existence of the industry implied that most of the fish species in the Cross River inland wetlands are detritivores during this period.

\subsection{Fecundity, Gonadosomatic Index and Egg Size}

Disparity was noted between fecundity of fish in this study area before establishment of industry and that of fish populations six years after the existence of the industry. The higher values of fecundity among populations before establishment of industry can be attributed to the greater abundance of food in the river pre-industry period. Pre-industry fish species of the Cross River were therefore more superior than post-industry and can be better broodstocks in the farms. Such related differences in fecundity had been observed [45-48] and were attributed to environmental factors such as differential abundance of food and water quality.

Fecundity may be reduced if individual fish mature at a smaller size, and individuals in poorer condition may experience increased mortality during environmentally stressful period [49]. Small egg size implies that survival 
rate of the progeny will be low [29]. Therefore, the larger egg sizes of fish species during pre-industry period implied that pre-industry Cross River provided more suitable habitat for the species.

The low GSI, fecundity and variation in the egg sizes observed for species during post-industry period may be attributed to the sudden change in the environmental factors due to effluents discharged from the wood processing industry. Similar observations have been reported [50]. A change in the environmental factors results in significant changes in the egg size [51]. The implication of these results is that the reproductive potential of fish species in Cross River is greatly affected by the environmental factors and human activities.

\section{REFERENCES}

[1] Food and Agriculture Orgnization (FAO), African Fisheries and the Environment: in Food and Agriculture Organization of the United Nations, Italy, 1991.

[2] J. Elkington, "Beware of the Wrath of Dsiris," New Science, Vol. 68, 1975, pp. 626-268.

[3] R. L. Welcome, "River Fisheries," FAO Fisheries Technical Paper, Vol. 262, 1985, pp. 330.

[4] Food and Agriculture Organization (FAO), "Role of Fisheries Technology in Development of Inland Floodplain in Africa," In: Symposium on River and Floodplain Fisheries in Africa, CIFA Technical Paper, No. 5, 1988, pp. 12-18.

[5] Food and Agriculture Organization (FAO), Training for Agriculture and Rural Development, Rome, 1986.

[6] B. D. Olaosebikan and A. Raji, "Field Guide to the Nigerian Fresh Water Fishes," Federal College of Freshwater Fisheries Technology, New Bussa, Nigeria, 1998.

[7] Federal Department of Fisheries, Presentation on the Fisheries Sub-Sector at the Presidential Forum, Abuja, 2003.

[8] D. M. Jamu and O. A. Ayinla, "Potential for the Development of Aquaculture in Africa," NAGA, Vol. 693, 2003, pp. 9-13.

[9] R. P. King, "New Observations on the Trophic Ecology of Liza Grandisquamis (Valenciennes, 1836) (Pisces: Mugillidae), in the Bonny River, Niger Delta, Nigeria," Cybium, Vol. 12, No. 1, 1988, pp. 23-36.

[10] P. M. Rosenberg, H. V. Danks and D. M. Lemhkyhi, "Importance of Insects in Environmental Impact Assessment," Environmental Management, Vol. 10, 1986, pp. 773-783.

[11] N. S. Clair, L. M. Perry and F. P. Gene, "Chemistry for Environmental Engineering and Science," 5th Edition, Mcgraw-Hill, New York, 2003.

[12] Federal Environmental Protection Agency, Our National Environmental Goals, Special Publication No.3, Lagos, 1989.

[13] E. O. Ita, "Inland Fisheries Resources of Nigeria," CIFA,
Food and Agriculture Orgnization, Rome, 1993.

[14] I. A. Butt, Report on the Industrial Pollution of Jakara Dam. Ministry of Health, Kano State, Nigeria, 1985.

[15] H. A. Adeniji and I. G. Mbagwu, Study of Physico-Chemical Characteristic of Some Heavy Metals in Jankara Reservoir, NIFFR Annual Report, Kano State, 1990.

[16] E. O. Anko and A. A. Eyo, "Fisheries Department, Ministry of Agric. Nigeria with Special Reference to Cross River State," Abstracts of the 17th Annual Conference of Fisheries Society of Nigeria (FISON), 2001.

[17] American Public Health Association, Standard Methods for the Examination of Water and Waste Water, Washington D.C., 1987.

[18] M. Elvira, "Taxonomic Revision of the Genus Chondrostoma Agassi 1835 (Pisces: Cyprinidae)," Cybium, Vol. 11, 1987, pp. 111-198.

[19] F. Erk'akan, T. T. Nalbant and S. C. Ozeren, "Seven New Species of Barbatula Three New Species of Schistura and a New Species of Seminemacheilus (Ortariophysi: Balitoridae: Nemachellinae) from Turkey," Journal of Fisheries International, Vol. 2, 2007, pp.69-85.

[20] G. G. Teugel, "Prelimnary Results of Morphological Study of Five African Species of the Subgenus Clarias (Pisces: Clariidae)," Journal of Natural History,Vol. 16, 1982, pp. 439. doi:10.1080/00222938200770351

[21] W. Fischer, M. Schneider and M. L. Bauchot, "Mediterranee et Mer Noire Zone De Peche 37," Revision 1, Volumn II, Vertebres, Rome, 1987.

[22] D. Pauly, "Fish Population Dynamics in Tropical Water: A Manual for Use with Programmable Calculators," Iclarm Studies and Reviews, Vol.8, 1984, pp.325.

[23] J. A. Zar, "Biostatistical Analysis," Prentice Hall, New Jersey, 1984.

[24] W. E. Ricker, "Computations and Interpretations of Biological Statistics of Fish Populations," Bulletin of the Fisheries Research Board of Canada, Vol. 191, 1975, pp. 201-210.

[25] V. O. Sagua, "Aquaculture and Fisheries Development in Nigeria," The 12th Annual Conference of Agriculture Society of Nigeria, University of Ife, 1979.

[26] A. C. Simpson, "The Fecundity of Plaice," UK Ministry of Agriculture and Fisheries, Fisheries and Food Investigation, Vol. 217, 1951, pp. 3-27.

[27] T. B. Bagenal, “Age and Growth,” In: T. B. Bagenal, Ed., Fish Production in Freshwater, Blackwell, Oxford, London, 1978, pp. 120-128.

[28] V. L. DE Vlaming, "The Effect of Temperature and Photoperiod on Reproductive Cycling in the Estuarine Gobiid Fish (Gillichthys mirabilis)," Fishery Bulletin, Vol. 73, 1982, pp. 1137-1157.

[29] A. M. A. Imevbore, "Some preliminary observation on the sex-ratio and fecundity of the fish in River Niger," In: S. A. Vissar, Ed., Kainji-A Nigerian Man-Made Lake, NISER, Ibadan, 1970. 
[30] P. B. Bayley, Caracteristicas de inundacion de los rios y areas de Captacion en la Amazonia peruana. Inf. No. 81 Institute del mar del peru (IMARPE), Peru, 1981.

[31] P. McCully, "Silenced Rivers: The Ecology and Politics of Large Dams," Zed Books Ltd., 1996.

[32] T. Bhukaswan, "Management of Asian Reservoir Fisheries," FAO Fisheries Technical Paper, Vol. 207, Rome, 1980.

[33] W. A. Evans and J. Vanderpuye, "Early Development of the Fish Populations and Fisheries of Volta Lake," Geophysical Monograph, Vol. 17, 1973, pp. 114-120. doi:10.1029/GM017p0114

[34] E. K. Balon and A. G. Coche, "Lake Kariba, a Man-Made Ecosystem in Central Africa," Monographiae Biologicae, Vol. 24, 1974, pp. 767.

[35] T. Petr, "Hydrobiology and Fisheries Problems of the Nyumba ya Mungu Man-Made Lake in Tanzania," The African Journal of Tropical Hydrobiology and Fisheries, Vol. 4, No. 1, 1975, pp. 39-50.

[36] T. Quarcoopome and F. K. Y. Amevenku, "Fish Fauna of the Weija Reservoir-28 Years After Impoundment," CSIR-WRI Technical Report, 2006.

[37] M. Abhijit, "Origin and Evolution the Deep-Sea Fauna," Journal of the Indian Ocean, Vol. 5, pp. 251-253.

[38] P. A. Large, P. Loranze and J. G. Pope, "Survey Estimates of the Overall Size Composition of the Deep-Sea Fish Species before and after Exploitation," ICES, Center for Environment, Fisheries and Aquacultural Sciences, Lowesoft, U.K., 1999.

[39] R. J. Wooton, "The Effect of Size of Food Ration on Egg Production in the Female Three-Spined Stickleback, Gasterosteus Aculeatus," The Journal of Fish Biology, Vol. 5, 1979, pp. 89-96.

[40] R. P. King, O. M. Udodiong, E. C. Ekwali and N. A. Nkanta, "Some Aspects of the Trophic Biology of Iiisha
Africana (Teleostei, Pristigasteridae) in Qua Iboe Estuary, Nigeria," African Journal of Ecology, Vol. 105, 1991, pp. 261-274.

[41] E. R. Akpan, "Seasonal Variability in Phytoplankton Biomass in Relation to Physico-Chemical Changes in the Cross River Estuaries of Eastern Nigeria Ph.D Thesis," University of Calabar, 1994.

[42] G. A. Rounsefell and W. H. Everhart, "Fishery Science, its Methods and Applications," John Wiley and Sons Inc., New York, 1957.

[43] T. K. Pitt, "Fecundity of American Plaice, Hippoglossoides Platessoides (F) Fromgrand Bank and New Found Land Areas," Journal of the Fisheries Research Board of Canada, Vol. 21, 1964, pp. 507-512.

[44] F. Nagasaki, "The Fecundity of Pacific Herring, Clupea Pallasi, in British Columbia Coastal Waters," Journal of the Fisheries Research Board of Canada, Vol. 15, 1958, pp. 313-330.

[45] S. S. E. Palacious, Estudio biologico pesquero de la tilapia Oreochromis aureus (Steindachner, 1864) en la Presa Benito Juarez, Oaxaca, Mexico, en 1993, Ciencia Pesquera, No. 11, 1995, pp. 54-61.

[46] B. J. Shuter, J. A. MacLean, F. E. J. Fry and H. A. Regier, "Stochastic Simulation of Temperature Effects on FirstYear Survival of Small-Mouth Bass," Transactions of the American Fisheries Society, Vol. 109, 1980, pp. 1-34.

[47] F. E. Asuquo, E. E. Ntekim, A. O. Eja, A. O. Ekwu, O. O. Ogri and E. S. Bassey, "Post Impact Assessment of Cross River Coastal Areas Affected by Mobil (Idoho) Oil Spillage," Report submitted to Cross River State Government, 1998.

[48] W. O. Odiete, Environmental Physiology of Animals and Pollution, Diversified Resources, Lagos, 1999. 